\title{
CYSTATIN C AS A SURROGATE MARKER FOR EVALUATING GLOMERULAR FILTRATION RATE IN ACUTE KIDNEY INJURY
}

\author{
Davendra Kumar1, Ajay Kumar Mishra², Jalees Fatima3, Mehboob Subhani Siddiqui', Moidur Rehman ${ }^{5}$ \\ ${ }^{1}$ Associate Professor, Department of Medicine, Era's Lucknow Medical College, Lucknow, Uttar Pradesh. \\ ${ }^{2}$ Associate Professor, Department of Medicine, Era's Lucknow Medical College, Lucknow, Uttar Pradesh. \\ 3Professor, Department of Medicine, Era's Lucknow Medical College, Lucknow, Uttar Pradesh. \\ 4 Professor, Department of Medicine, Era's Lucknow Medical College, Lucknow, Uttar Pradesh. \\ 5Senior Resident, Department of Medicine, Era's Lucknow Medical College, Lucknow, Uttar Pradesh.
}

ABSTRACT
BACKGROUND
The gold standard for measuring GFR has practical limitations in clinical practice; instead it is estimated by use of the serum
concentration of endogenous filtration markers. The objective of this research was to compare serum cystatin $\mathrm{C}$ with serum
creatinine for Estimating Glomerular Filtration Rate (eGFR) in acute kidney injury and to determine whether elevated serum cystatin
C has an impact on mortality in the presence of kidney injury.

\section{METHODS}

This prospective observation study was carried out for 18 months in our institution. It included all indoor Acute Kidney Injury (AKI) patients more than 18 years, admitted in the Department of Medicine of our tertiary care centre. The renal function of the patients was evaluated by testing for serum creatinine and serum cystatin C. Serum creatinine based Cockcroft and Gault (CG) equation and Estimated GFR (e-GFR) with Modification of Diet in Renal Disease (MDRD) equation were compared with serum cystatin C based e-GFR Hoek and Larsson equations. All-cause mortality was ascertained by examination of death certificates, inpatient hospital records.

\section{RESULTS}

A total of 90 patients were enrolled during the study. The mean serum creatinine (mg/dL) 3.455 \pm 1.77 , serum cystatin (mg/L) $2.932 \pm 1.13$, and creatinine clearance (CG) 27.16 \pm 16.96 , eGFR-MDRD (mL/min.) 24.94 \pm 17.95 , eGFR-Larsson 31.60 \pm 17.36 and eGFRHoek 29.00 \pm 17.39 . The correlation of the Larsson and Hoek cystatin $\mathrm{C}$ based GFR estimates ( $\mathrm{r}=0.94 ; \mathrm{p}=<0.001)$ and MDRD and CG serum creatinine based GFR estimates $(r=-0.93 ; p<0.001)$ were highly significant. In multiple logistic regression analysis which included age, serum creatinine and serum cystatin $C$ as variables, only serum cystatin $C(p=0.046)$ was found to be a significant factor influencing mortality in acute kidney injury.

\section{CONCLUSIONS}

The present study suggests that the cystatin C-based prediction equation achieved a diagnostic performance that was at least as good as the creatinine based formulas. Serum cystatin $C$ has superior diagnostic value than serum creatinine in influencing mortality in patients with acute kidney injury.

\section{KEYWORDS}

Cystatin C, Glomerular Filtration Rate, Acute Kidney Injury.

HOW TO CITE THIS ARTICLE: Kumar D, Mishra AK, Fatima J, et al. Cystatin C as a surrogate marker for evaluating glomerular filtration rate in acute kidney injury. J. Evolution Med. Dent. Sci. 2016;5(34):1869-1871, DOI: 10.14260/jemds/2016/441

\section{INTRODUCTION}

The gold standard for measuring GFR (e.g. Using insulin clearance, urinary clearance of exogenous radioactive markers (125I-iothalamate and 99 mTc-DTPA (Diethylenetriamine-Pentaacetate)), has practical limitations in clinical practice; instead it is estimated by use of the serum concentration of endogenous filtration markers. GFR is presently being monitored by serum creatinine concentration and calculated creatinine clearance using the Cockcroft and Gault equation (CG) or Modification of Diet in Renal Disease study (MDRD) equation.[1],[2],[3]

Financial or Other, Competing Interest: None

Submission 28-03-2016, Peer Review 08-04-2016,

Acceptance 12-04-2016, Published 26-04-2016.

Corresponding Author:

Dr. Davendra Kumar,

Associate Professor

Department of Medicine,

Era's Lucknow Medical College,

Lucknow, Uttar Pradesh.

E-mail: dr.dr_devendra@rediffmail.com

DOI: $10.14260 /$ jemds $/ 2016 / 441$
The previous studies have suggested that serum cystatin C concentration is a better indicator of GFR than the serum creatinine concentration in patients with spine injury, liver cirrhosis, diabetes, mild-to-moderate impaired kidney function and in elderly patients. ${ }^{[4],[5],[6],[7],[8] ~ T h e ~ a i m ~ o f ~ t h i s ~}$ study was to compare serum cystatin $C$ with serum creatinine for Estimating Glomerular Filtration Rate (eGFR) in acute kidney injury and to determine whether elevated serum cystatin $\mathrm{C}$ has an impact on mortality in the presence of kidney injury.

\section{MATERIAL AND METHODS}

This prospective observation study was approved by the ethics committee and was performed at our tertiary care centre from February 2013 to July 2014. The study included all indoor Acute Kidney Injury (AKI) patients more than 18 years, admitted in the Department of Medicine of our tertiary care centre. Patients with deranged thyroid function, chronic renal failure and on corticosteroid treatment were excluded from the study. The patients were followed up for 3 months after discharged from the hospital. 
Acute kidney injury was defined as a serum creatinine level detected over normal range $(>1.2 \mathrm{mg} / \mathrm{dL})$ at presentation or showed increase of $50 \%$ or more from the baseline value. The renal function of the patients was evaluated by testing for serum creatinine and serum cystatin $C$. The serum cystatin $C$ and serum creatinine values were measured simultaneously and analysed at the time of admission. Samples were assayed immediately or stored at $-20^{\circ} \mathrm{C}$. Cystatin $\mathrm{C}$ assay (Human Cystatin C ELISA kits; BioVendor LLC, Candler, NC, USA) employed the quantitative sandwich enzyme immunoassay assay (ELISA) with Microplates were pre-coated with monoclonal antibodies specific for cystatin $\mathrm{C}$.

Serum creatinine was used to estimate creatinine clearance by Cockcroft and Gault (CG) equation and estimated GFR (e-GFR) with the four-variable Modification of Diet in Renal Disease (MDRD) equation.

1. e-GFR (MDRD) (mL/min $/ 1.73 \mathrm{~m} 2)=186 \times$ (Serum creatinine) $-1.154 \times$ (Age) $-0.203 \times(0.742$ if female).

2. e-GFR $(C G)=[(140-$ Age $) \times$ Mass $($ in $\mathrm{kg})] \backslash[72 \times$ Serum creatinine (in $\mathrm{mg} / \mathrm{dL}$ ).

GFR was calculated also according to cystatin C equations.

1. e-GFR (Hoek) $(\mathrm{mL} / \mathrm{min})=80.35 /$ serum cystatin C-4.32.

2. e-GFR (Larsson) $(\mathrm{mL} / \mathrm{min})=99.43 \times$ serum cystatin $\mathrm{C}$ 1.583.

All-cause mortality was ascertained by examination of death certificates, inpatient hospital records.

\section{Statistical Analysis}

All statistical analysis was performed using SPSS version 20.0 (SPSS Inc., Chicago, IL, USA). Data were presented as mean \pm SD or $\mathrm{n}(\%)$. The results of comparing the correlation between two continuous variables were indicated by the correlation coefficient (r) using correlation analysis. Reference values were defined the maximum sum of sensitivity and specificity with over 0.6 of each value. The logistic regression test was performed to identify independent factors impacting mortality in acute kidney injury. A result was deemed statistically significant when $\mathrm{p}<0.05$.

\section{RESULTS}

A total of 90 patients were enrolled during the study. There were $68(75.6 \%)$ males and $22(24.4 \%)$ females. The mean age (Years) was $48.89 \pm 14.4$ (19-70), Weight (Kg) 60.3 \pm 12.0 (3880), BMI (kg/m2) 21.69 \pm 2.7 (16-30), and Body Surface Area (m2) 1.64 \pm 0.2 (1.13-1.98). (Table 1). Among 90 patients, 52 patients required emergency hospitalization. The most common causes of AKI observed were diarrhoea 63 (70\%) and sepsis 22 (24.4\%). The mean Serum Creatinine (mg/dL) $3.455 \pm 1.77$, Serum Cystatin (mg/L) 2.932 \pm 1.13 and creatinine clearance (CG) 27.16 \pm 16.96 , eGFR-MDRD (mL/min) 24.94 \pm 17.95 , eGFR-Larsson $31.60 \pm 17.36$ and eGFR-Hoek $29.00 \pm 17.39$ are shown in Table 1 .

The correlation of the Larsson and Hoek cystatin $\mathrm{C}$ based GFR estimates ( $r=0.94 ; \mathrm{p}=<0.001)$ and MDRD and CG serum creatinine based GFR estimates $(r=-0.93$; $p<0.001)$ were highly significant. During the study, 12 (13\%) patients expired and $11(12 \%)$ patients were lost in the followup after discharged from the hospital. The death group exhibited higher average serum cystatin $C(3.36 \pm 0.98 \mathrm{mg} / \mathrm{L}$ vs. $2.71 \pm 1.02 \mathrm{mg} / \mathrm{L}, \mathrm{p}=0.043$ ) as compared to the survival.

Whereas, serum creatinine in the death group was lower $(2.41 \pm 0.82 \mathrm{mg} / \mathrm{dL}$ vs. $3.23 \pm 1.27 \mathrm{mg} / \mathrm{dL}, \mathrm{p}=0.035)$ as compared to the survival group (Table 2). Multiple logistic regression analysis was performed to know the factors impacting mortality in patients with acute kidney injury. Among the variables which included age, serum creatinine, and serum cystatin $\mathrm{C}$, only serum cystatin $\mathrm{C}(\mathrm{p}=0.046)$ was found to be a significant factor influencing mortality in acute kidney injury (Table 3).

\begin{tabular}{|c|c|}
\hline Patient Characteristics & $n=90$ \\
\hline Age (Years) & $48.89 \pm 14.4(19-70)$ \\
\hline Male/Female & $68 / 22$ \\
\hline Weight (Kg) & $60.3 \pm 12.0(38-80)$ \\
\hline $\mathrm{BMI}\left(\mathrm{Kg} / \mathrm{m}^{2}\right)$ & $21.69 \pm 2.7(16-30)$ \\
\hline Body Surface Area $\left(\mathrm{m}^{2}\right)$ & $1.64 \pm 0.2(1.13-1.98)$ \\
\hline Serum Creatinine (mg/dL) & $3.45 \pm 1.8(0.9-9.10)$ \\
\hline Serum Cystatin (mg/L) & $2.91 \pm 1.1(0.88-5.20)$ \\
\hline eGFR-CG (mL/min) & $27.16 \pm 16.9(6.94-101.98)$ \\
\hline eGFR-MDRD (mL/min) & $24.95 \pm 17.9(4.8-105.5)$ \\
\hline eGFR-Larsson (mL/min) & $31.61 \pm 17.4(9.4-77.5)$ \\
\hline eGFR-Hoek (mL/min) & $29.00 \pm 17.4(11.13-86.99)$ \\
\hline \multicolumn{2}{|c|}{ Table 1: Baseline Characteristic of all Patients } \\
\hline
\end{tabular}

Data are shown as mean \pm standard deviation (SD).

\begin{tabular}{|c|c|c|c|c|c|}
\hline & Status & $\mathbf{n}$ & Mean \pm SD & $\mathbf{t}$ & $\mathbf{p}$ \\
\hline \multirow{2}{*}{$\begin{array}{c}\text { Serum } \\
\text { creatinine } \\
(\mathrm{mg} / \mathrm{dL})\end{array}$} & Dead & 12 & $2.41 \pm 0.82$ & \multirow[b]{2}{*}{-2.142} & \multirow[b]{2}{*}{.035} \\
\hline & Alive & 67 & $3.23 \pm 1.27$ & & \\
\hline \multirow{2}{*}{$\begin{array}{l}\text { Serum } \\
\text { Cystatin C } \\
\text { (mg/L) }\end{array}$} & Dead & 12 & $3.36 \pm 0.98$ & \multirow[b]{2}{*}{2.056} & \multirow[b]{2}{*}{.043} \\
\hline & Alive & 67 & $2.71 \pm 1.02$ & & \\
\hline \multirow{2}{*}{$\begin{array}{c}\text { MDRD } \\
(\mathrm{mL} / \mathrm{min})\end{array}$} & Dead & 12 & $32.14 \pm 13.64$ & \multirow{2}{*}{1.751} & \multirow{2}{*}{.084} \\
\hline & Alive & 67 & $24.02 \pm 14.97$ & & \\
\hline \multirow{2}{*}{$\begin{array}{l}\text { Cockcroft- } \\
\text { Gault } \\
\text { (mL/min) }\end{array}$} & Dead & 12 & $37.82 \pm 15.06$ & \multirow{2}{*}{3.073} & \multirow[b]{2}{*}{.003} \\
\hline & Alive & 67 & $25.38 \pm 12.52$ & & \\
\hline \multirow{2}{*}{$\begin{array}{c}\text { Hoek } \\
(\mathrm{mL} / \mathrm{min})\end{array}$} & Dead & 12 & $22.17 \pm 7.03$ & \multirow{2}{*}{-1.703} & \multirow{2}{*}{.093} \\
\hline & Alive & 67 & $31.11 \pm 17.85$ & & \\
\hline \multirow{2}{*}{$\begin{array}{c}\text { Larsson } \\
\text { (mL/min) }\end{array}$} & Dead & 12 & $27.20 \pm 10.34$ & \multirow{2}{*}{-1.280} & \multirow{2}{*}{.204} \\
\hline & Alive & 67 & $33.72 \pm 17.05$ & & \\
\hline
\end{tabular}

\begin{tabular}{|c|c|c|c|c|c|}
\hline & B & S.E. & Wald & df & $\begin{array}{c}\text { p- } \\
\text { value }\end{array}$ \\
\hline Age Year & .024 & .023 & 1.087 & 1 & .297 \\
\hline $\begin{array}{c}\text { Serum Cystatin C } \\
\text { mg/L }\end{array}$ & -.646 & .323 & 3.993 & 1 & .046 \\
\hline $\begin{array}{c}\text { Serum Creatinine } \\
\text { mg/dL }\end{array}$ & .630 & .465 & 1.833 & 1 & .176 \\
\hline Constant & 2.531 & 1.464 & 2.988 & 1 & .084 \\
\hline $\begin{array}{c}\text { Table 3: Multivariate Logistic Regression for Mortality } \\
\text { using Age, Serum Cystatin C and Serum Creatinine }\end{array}$ \\
\hline
\end{tabular}

\section{DISCUSSION}

The CG and MDRD equations have been evaluated in numerous published studies and widely applied. However, the equations have some well-known limitations.[9] Therefore, new alternatives like creatinine-based CKD-EPI equation, cystatin C-based formulas and equations that uses both serum creatinine and serum cystatin $\mathrm{C}$ were developed.[2],[10],[11],[12],[13],[14] In our study, we compared the widely used creatinine-based equations and cystatin C-based equations in patients with AKI. 
No difference between correlation coefficients of the creatinine based formulas and cystatin $\mathrm{C}$ formula was found. The results of the present study suggest that the cystatin $\mathrm{C}$ based prediction equation, which requires just one variable, achieved a diagnostic performance that was at least as good as the creatinine based formulas using more variables. Rule et al, in a prospective study, concluded that the cystatin $\mathrm{C}$ formula is complementary to the serum creatinine-based equations or can be used in place of the serum creatinine-based equations.[15]

Cystatin C is also a marker of inflammation and like many other markers of inflammation its plasma concentration may be higher in patients with decreased renal clearance. There is mounting evidence, however, that cystatin $\mathrm{C}$ may be a predictor of adverse outcomes independent of renal function.[16] In the study by Koenig et al, the association of serum cystatin $C$ with adverse outcome was independent of CRP and other factors known to influence cystatin C concentrations. ${ }^{[17]}$ In the present study, both serum creatinine and serum cystatin $\mathrm{C}$ concentrations as measured during hospitalization were significantly higher for the group exhibiting mortality during the course of the study period.

The death group within the first three months had an average serum cystatin C level of $3.36 \mathrm{mg} / \mathrm{L}$, while the survival group had an average level of $2.7 \mathrm{mg} / \mathrm{L}$, thus yielding a significant difference $(p=0.04)$. In multiple logistic regression analysis which included age, serum creatinine and serum cystatin $\mathrm{C}$, only serum cystatin $\mathrm{C}$ was found to be a significant independent factor influencing mortality in acute kidney injury. This suggests that in patients with serum cystatin $C$ concentrations of $3.36 \mathrm{mg} / \mathrm{L}$ or higher, there is a higher rate of mortality.

In conclusion, the results of the present study suggest that the cystatin C-based prediction equation achieved a diagnostic performance that was at least as good as the creatinine based formulas. Serum cystatin $\mathrm{C}$ has superior diagnostic value than serum creatinine in influencing mortality in patients with acute kidney injury.

\section{REFERENCES}

1. Cockcroft DW, Gault MH. Prediction of creatinine clearance from serum creatinine. Nephron 1976;16(1):31-41.

2. National Kidney Foundation. K/DOQI clinical practice guidelines for chronic kidney disease: evaluation, classification, and stratification. Am J Kidney Dis 2002;399(2 Suppl 1):S1-266.

3. Froissart M, Rossert J, Jacquot C, et al. Predictive performance of the modification of diet in renal disease and cockcroft-gault equations for estimating renal function. J Am Soc Nephrol 2005;16(3):763-73.

4. Dharnidharka VR, Kwon C, Stevens G. Serum cystatin C is superior to serum creatinine as a marker of kidney function: a meta-analysis. American Journal of Kidney Disease 2002;40(2):221-6.
5. Willems D, Wolff F, Mekahli F, et al. Cystatin C for early detection of renal impairment in diabetes. Clinical Biochemistry 2009;42(1-2):108-10.

6. Dhia RB, Hellara I, Harzallah O, et al. Evaluation of the renal function in type 2 diabetes: clearance calculation or cystatin C? Analyses de Biologie Clinique 2012;70(3):28794.

7. Hojs R, Bevc S, Antolinc B, et al. Serum cystatin C as an endogenous marker of renal function in the elderly. International Journal of Clinical Pharmacology Research 2004;24(2-3):49-54.

8. Hojs R, Bevc S, Ekart R, et al. Serum cystatin C as an endogenous marker of renal function in patients with mild to moderate impairment of kidney function. Nephrology Dialysis Transplantation 2006;21(7):1855-62.

9. Stevens LA, Coresh J, Greene T, et al. Assessing kidney function-measured and estimated glomerular filtration rate. The New England Journal of Medicine 2006;354(23):2473-83.

10. Hoek FJ, Kemperman FAW, Krediet RT. A comparison between cystatin $\mathrm{C}$, plasma creatinine and the cockcroft and gault formula for the estimation of glomerular filtration rate. Nephrology Dialysis Transplantation 2003;18(10):2024-31.

11. Larsson A, Malm J, Grubb A, et al. Calculation of glomerular filtration rate expressed in $\mathrm{mL} / \mathrm{min}$ from plasma cystatin $\mathrm{C}$ values in $\mathrm{mg} / \mathrm{L}$. Scandinavian Journal of Clinical and Laboratory Investigation 2004;64(1):25-30.

12. Hojs R, Bevc S, Ekart R, et al. Serum crystatin C-based equation compared to serum creatinine-based equations for estimation of glomerular filtration rate in patient with chronic kidney disease. Clinical Nephrology 2008;70(1):10-7.

13. Tidman M, Sjostrom P, Jones I. A comparison of GFR estimating formulae based upon s-cystatin $\mathrm{C}$ and $\mathrm{s}$ creatinine and a combination of the two. Nephrology Dialysis Transplantation 2008;23(1):154-60.

14. Stevens LA, Coresh J, Schmid CH, et al. Estimating GFR using serum cystatin $\mathrm{C}$ alone and in combination with serum creatinine: a pooled analysis of 3,418 individuals with CKD. American Journal of Kidney Diseases 2008;51(3):395-406.

15. Rule AD, Bergstralh EJ, Slezak JM, et al. Glomerular filtration rate estimated by cystatin $\mathrm{C}$ among different clinical presentations. Kidney International 2006;69(2):399-405.

16. Hansson LO. Cystatin C: an emerging marker for pre-timely mortality. Journal of Internal Medicine 2010;268(2):1068.

17. Koenig W, Twardella D, Brenner $\mathrm{H}$, et al. Plasma concentrations of cystatin $\mathrm{C}$ in patients with coronary heart disease and risk for secondary cardiovascular events: more than simply a marker of glomerular filtration rate. Clin Chem 2005;51(2):321-7. 